\title{
The moral status of the human embryo: a tradition recalled
}

\author{
G R Dunstan Professor Emeritus of Moral and Social Theology, University of London
}

\section{Editor's note}

In this paper a distinguished Anglican theologian argues that the claim to absolute protection for the human embryo 'from the beginning' is a novelty in the Western Christian and specifically Roman Catholic moral traditions.

Instead the author offers evidence supporting his claim that the Christian tradition has until the late nineteenth century attempted to grade the protection given to the nascent human being according to the stages of its development.

\section{I}

There are compelling reasons, theological, philosophical and practical, why moralists should affirm the sacredness of human life. The task is the more urgent when every day brings news of assassinations, murder by terrorists, secret police and soldiery under the command of despotic governments; of wars, invasions and insurrections; of widespread death from starvation; of torture and unjust imprisonment as instruments of political oppression. The memory of inhumane 'experiments' imposed by medical scientists under the Nazi and other regimes is still painful, and dictates continual vigilance. The spread of clinically induced abortions throughout the technically-advanced countries of the world, as social expedients well beyond therapeutic necessity, calls into question the dedication of the medical profession as the servant and protector of life. It is to be expected, therefore, that those who feel most strongly that the sacredness of human life is under new threat should stake their claim at the highest conceivable point; and, indeed, that despairing of any 'half-way house' or defensible intermediate point, should claim 'absolute' protection from the moment 'when life begins': unless a stand is made there, no life is safe; whatever experiment or disposal is thought to be expedient will somehow be 'justified'.

Desperate situations evoke desperate remedies; but not always the best remedies. Upon examination the absolutist argument proves to offer less security than is

\section{Key words}

Human embryo; abortion; human rights; sanctity of life; animation; quickening; human fetus. claimed for it. First, its empirical base is not secure. The claim that life begins 'at the moment of conception' is disputed by biologists competent to judge. Their contention that 'life' exists independently in sperm and egg-cell before fertilisation, that not all products of conception from human gametes are recognisably human, and that, given the range of convolutions possible during the early stages of cell division, conception does not invariably determine the identity of the human person, is not overthrown by mere dogmatic assertion and re-assertion to the contrary. One of the three bodies representing the Roman Catholic community which gave evidence to the Warnock Committee, the Social Welfare Commission of the Catholic Bishops' Conference (England and Wales), has conceded the point in so far as it professes agnosticism as to when precisely life begins, though it would 'err on the side of caution' in giving the embryo the benefit of the doubt, and so in claiming protection for it from, 'the beginning' whenever that is (1).

Secondly, it must be replied that in neither Christian morality, Jewish morality nor English law is human life given absolute protection at any stage. It enjoys a very high presumption in its favour, a presumption rebuttable only in terms recognised by morality and law. Morality and law may not always coincide on the definition of those terms; but that they exist there is no dispute. To claim an 'absolute' right to life for the embryo or fetus would be morally odd: the claim is inconsistent with other accepted moral claims.

Thirdly, the claim to absolute protection for the human embryo 'from the beginning' is a novelty in the Western, Christian and specifically Roman Catholic moral traditions. It is virtually a creation of the later nineteenth century, a little over a century ago; and that is a novelty indeed as traditions go. To recall that tradition is the purpose of this paper.

\section{II}

The tradition is, in fact, well documented in authentic Roman Catholic scholarship. Many of the evidences for it are set out in the Dictionnaire de Theologie Catholique (2) and the Dictionnaire de Droit Canonique (3); others become evident when the language of the 
tradition is recognised and given its contextual significance. The main evidences are found in the philosophical discussion of animation - the relation of the soul to the human person - and in the moral and legal sanctions for abortion. The purpose of this paper, however, is not to re-open the philosophical speculations upon animation nor to discuss sanctions for abortion; it is simply to recall the fact of the tradition and of its persistence in English law and Catholic moral theology and canonical jurisprudence. The philosophical notion of animation did not create the tradition - it existed before Aristotle formulated the theory; and its persistence long after the philosophical theory had lost its appeal and its point suggested that it ministered satisfactorily to a perennial human need. The need is to have some practical working rule by which to adjust conflicting and legitimate human claims in areas of moral judgement where absolutes are unattainable.

We may pick up the tradition among the civilisations of the Levant out of which some of the laws of the Old Testament were shaped. The Babylonian Code of Hammurabi prescribed penalties for striking a woman so as to cause her to lose the child of her womb. The penalties were graded according to her status: ten shekels, or five, or two, according to whether she were the daughter of a noble or freeman, a commoner or villein, or a slave respectively. And if she also died, the penalties were similarly graded: the life of the assailant's daughter for the first, diminishing fines for the second and third (4). The Hebrew law of Exodus 21: $22 \mathrm{ff}$ similarly relates the penalties to the hurt to the woman, though without explicit social grading:

'And if men strive together, and hurt a woman with child, so that her fruit depart, and yet no mischief follow; he shall be surely fined, according as the woman's husband shall lay upon him; and he shall pay as the judges determine. But if any mischief follow, then thou shalt give life for life, ...'

The Assyrian laws were similar, punishing the assault severely as an invasion of the husband's property. The Hittites, however, grounded their penalties, not on the social status of the mother or on the hurt done to her, but on the gestational age of the fetus: ten shekels of silver for a ten months fetus, five shekels if the pregnancy were in its fifth month (5).

There follows a highly significant departure. When the Hebrew text of Exodus was translated into Greek, in the Septuagint version (LXX), in the third century $\mathrm{BC}$ the Hittite principle, of relating the penalty to gestational age, was substituted for the other: the fine is payable if the fetus is me exeikonismenon - not yet so formed as to be a copy of portrayal of the human form; if it were exeikonismenon, then life was to be given for life. The LXX was followed in the Old Latin versions, evidenced before the end of the second century AD-as it was closely paralleled by the Samaritan and Karaite versions (6). The Septuagint was the version most commonly used by the early Christian fathers (as welए as by the New Testament writers); and the language of the Old Latin versions became the language of the

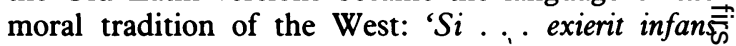
nondum formatus. . .; si autem formatus fuerit. . .' $\mathrm{S} \dot{6}$ Jerome's translation of the Hebrew text into the Latirf of the Vulgate, towards the end of the fourth century $\frac{\bar{s}}{5-}$ did not overthrow the Septuagint tradition. It is then distinction of the LXX and Old Latin versions which appears throughout the canonical legislation of the West. It did so, we may surmise, because the mora $\vec{b}$ rule was consistent both with current philosophicai perceptions of the relation of soul and body, and with the physiology developed in Hippocratic and Galenit medicine.

The Hippocratic corpus records a variety of $\dot{5}$ observations on fetal growth. For 'formation' estimateșare for 35 , or 40 , or 50 days; for the first distinguishin $\$_{0}$ of limbs, about 40 days; for movement, 70, 80, 90, or 100 days; for completion to birth, from 210 to 300 days (7). Philosophical speculation was related to thesez observations. In Aristotle's usage, the 'soul' ( $p$ syche) of animating principle (from the Latin, anima) was tha which gave to a substance or organism its characteristi $\overrightarrow{\xi_{0}}$ form. So, in a passage in On the Generation of animal $\$$ (8) Aristotle attributed to the earliest embryo vegetative existence animated or informed by 'nutritive' soul; to the later embryo, resembling a little animal, a 'sensitive' soul; to the formed fetus recognisably human, a 'rational' or 'intellectual' soul encapsulating not replacing the other two (9). If remains to add that since the anatomy of the male्ब distinguished its humanity by about 40 days, while doubt remained about the female until 90 days (10) these were the limits within which, in the later mora? tradition, a fetus was held to be formatus et animatus an $\overline{\text {. }}$ so indisputably human. And whereas the deliberate destruction of nascent human life at any stage was helos to be morally offensive, the penalties were graded on the basis of that distinction.

Before the catena of evidences is displayed, notics must be taken of two apparent dissentients from the tradition. The first was Tertullian, the North Africar lawyer who wrote vigorously in defence of Christianity. against charges of human sacrifice, secret homicides infanticide and other enormities. He wrote:

'For us, indeed, homicide having been forbidden once and for all, it is not lawful to destroy what is conceived in the womb even while the blood is being drawn int $\frac{\varrho}{\sigma}$ a human being. To deny birth is to hasten homicide for it makes no difference whether you snatch away the soul after birth or destroy it while coming to birth Even the man who is yet to be is a man, just as everyD fruit is already present in its seed' (11).

Although Tertullian does not specify any stage of gestation, it would appear from his use of the word\$ dum adhuc sanguis in hominem delibatur that his prohibition would apply early as well as late; though i. 
is to be observed that Tertullian was by no means accounted orthodox in other of his controversial opinions, particularly in his 'transducianism' or peculiar belief that the soul (anima) derived from the parental seed, a belief that would give added importance to the early embryo.

A stronger witness, not tainted by heterodoxy, is St Basil (c 330-79), Bishop of Caesarea, who expressly repudiates the tradition of which we write:

'A woman who deliberately destroys a fetus is answerable for murder. And any fine distinction as to its being completely formed or unformed (ekmemorphomenou kai anexeikonistou) is not admissible among us' (12).

Whether or not St Basil's judgement persisted in the Greek Churches, the present writer does not know, for he has not pursued the question.

The first witness against St Basil, however, and in the long chain of evidence in the West, is Basil's own brother, St Gregory of Nyssa (c 330-395). For him, Basil's 'fine distinction' between unformed embryo and formed, animated fetus is sufficiently accepted as to be used as a premiss in a theological argument:

'For just as it would not be possible to style the unformed embryo a human being, but only a potential one - assuming that it is completed so as to come forth to human birth, while so long as it is in this unformed state it is something other than a human being - so our reason cannot recognise as a Christian one who has failed to receive, with regard to the entire mystery, the genuine form of our religion' (13).

This distinction persisted through the centuries in the determination of what is or is not homicide, and in the determination of canonical penances for causing a miscarriage.

First, St Augustine of Hippo (354-430):

'If what is brought forth is unformed (informe) but at this stage some sort of living, shapeless thing (informiter), then the law of homicide would not apply, for it could not be said that there was a living soul in that body, for it lacks all sense, if it be such as is not yet formed (nondum formata) and therefore not yet endowed with its senses' (14).

The Celtic Penitentials were as severe as they were precise in their penal tariffs. The Bigotian canons, and the Canones Hibernenses (c AD 665) prescribe three and three and a half years on bread and water respectively for the destruction of 'the liquid matter of the infant in the womb' (the usual term in Galenic anatomy for the forming embryo); but fourteen and seven and a half years respectively for the destruction of 'flesh and soul' (carnis et animae). The Old Irish Canons have three stages: 'after it has become established in the womb', ( $31 / 2$ years); 'if the flesh has formed' ( 7 years); and 'if the soul has entered it' (14 years) (15).
The canon law and moral discipline of the Catholic West did not develop on Celtic lines; but the basic distinction remained entrenched. Pope Innocent III, that great legislator, issued in 1211 a canon (16) determining for what offence a priest incurred 'irregularity', that is, was suspended from his priestly ministrations. So, if he has been a party to a miscarriage, 'if the conceptus is not yet quickened (vivificatus) he may minister; otherwise, he must abstain from the service of the altar.'

The point was taken up by Raymond de Penafort (1185-1275), a major canonist, in words which influenced incidentally the formation of the English common law. He is answering the question: if someone strikes a pregnant woman or gives her poison (or she herself takes it) so that she miscarries or does not conceive, should he be adjudged a homicide or irregular? He answers:

'If the fetus (puerperium) is already formed or animated (formatum sive animatum), that is truly homicide if because of that blow or potion the woman miscarries, for he has killed a man. If however it is not yet animated, it is not said to be homicide so far as concerns irregularity, but it is accounted homicide in regard to penance' (17).

Henry of Bracton, Raymond's contemporary, writing on the subject in his treatise On the Laws and Customs of England, used words so close to Raymond's as to suggest (18) either quotation from Raymond or use of a common source. His subject is the division of the crime of homicide:

'Should anyone strike a pregnant woman or give her poison on account of which she miscarries, if the fetus is already formed and animated, and especially if animated, he commits homicide.'

And among his exceptions to the criteria for the recognition of legal personality at birth:

'Item, if the issue is not formed as a human being (non formatus ut homo) but as a monster' (19).

The canon law and the English common law were thus, for their respective purposes, in step. Inevitably the philosophical notion of animation became identified with the subjective experience of quickening; so quickening became a determining point for various purposes in the common law. Blackstone wrote in his Commentaries, in 1770 (20), that 'Life begins in contemplation of law as soon as an infant is able to stir in the mother's womb'; and, relying on Coke from the seventeenth century, 'to be saved from the gallows a woman must be quick with child - for barely with child, unless he be alive in the womb, is not sufficient'. And so the law operated: in July 1387 at the Winchester assize, a gentlewoman was condemned to 
death for consenting and aiding in the murder of her husband by his chaplain, but her execution was respited because of her pregnancy; the judgement was confirmed in the King's Bench after Easter and she was executed on 17 April 1388 (21).

Meanwhile the moral tradition continued without such crudities, and finds expression in two other great figures of the thirteenth century, St Thomas Aquinas and Dante. St Thomas is answering the question: Is he who kills another by accident guilty of homicide? Referring to the law of Exodus 21: 22-3, he writes

'He who strikes a pregnant woman by that act puts himself in the wrong, so that if death should result either for the woman or for the animated fetus (puerperii animati) he cannot escape the crime of homicide, particularly since it is so obvious that death may result from such a blow' (22).

It is indicative of how far the Aristotelian tradition is forgotten, even among such scholars as the Dominican editors of the new Blackfriars edition of the Summa, that the word animati is overlooked in Marcus Lefébure's translation in volume 38 of that edition. Yet St Thomas meant what he wrote: when he writes of the relation of the soul to embryonic growth he quotes Aristotle precisely, as we have quoted him above.

'In the natural way of generation the progression is from the imperfect to the perfect. Hence, just as in the generation of man first comes a living thing, then the animal, and finally man, so things which merely live, like plants, commonly exist for the sake of animals, and animals for the sake of men' (23).

' . . this prime factor in intellectual activity, whether we call it mind or intellectual soul anima intellectiva), is the formative principle of the body. And this is how Aristotle proves it in the De Anima' (24).

‘. everything has its species determined by its formative principle. So we are left with this, that the intellective principle is the formative principle determing man as a species'.

'Besides, Aristotle says that the embryo is an animal before it is a man. . . . So the intellectual soul is not the same as the sensitive soul in man, but presupposes it as the matter it energizes' (25).

$\therefore$. the conception of a male is not completed (non perficitur) until about the fortieth day, as Aristotle says in the 9th de Animalibus; that of a female not until about the ninetieth day' (26).

It was to these passages in St Thomas, and so to Aristotle behind him, that Catholic moralists were appealing down to the end of the nineteenth century.

Dante, meanwhile, embodied the same doctrine in his poetry. Statius, climbing with Dante to the seventh cornice of the mount of Purgatory, explains theT generation of the embryo from the mingling of paterna $\vec{F}$. seed with maternal blood, and its passing through the? vegetable and animal stages to become a fetus:

Apri a la verità che viene il petto;

e sappi che sì tosto come al feto

l'articular del cerebro è perfetto, lo motor primo a lui si volge lieto sovra tant'arte di natura, e spira

spirito novo di virtù repleto, che ciò trova attivo quivi, tira

in sua sustanzia, e fassi un'alma sola, che vive, e sente, $e$ sè in sè regira.

Open thy heart now and the truth expect; and know that to the fetus, once the brain is shaped there in each is last minute respect, $\vec{\circ}$ the primal Mover turns himself, full fain of nature's masterpiece, work so fair, and inbreathes a new spirit, which draws amain, replete with power, all if finds active there into its substance and becomes but one quick, sentient soul, of i own self aware (27).

It is to be noted that sentience and awareness, which Dante attributes to the fetus into which, now that it is formed enough to receive it, God has inbreathed the soul, are also the capacities which modern embryologists cite as determining the point at which the fetus becomes an ethical persona, that is, a being with its own claims and interests which investigator $\overline{0}$ and researchers must not violate (28). These capacities depend, of course, on the stage of development of the nervous system.

What Statius described was standard mediaeva teaching: three stages of ensoulment, the process being completed with the full form of the body at about forty. days. It appears in an early thirteenth centurj: compilation made possibly in Gloucester Abbey (29) It was elaborated by the celebrated Tudor surgeoro Thomas Vicary (30). He cites as his authorities 'the noble Philosophers, as Galen, Auicen (Avicenna) anक्ष Bartholomeus', but his material is recognisabl Aristotelian also; and certainly it would hardly survive the Vesalian revolution in anatomy. He describes the development of the 'Embruon' into the 'Fettus' in fout stages, of which

'The fourth and laste, as when al the other members beo perfectly shapen, then it receyeth the soule wyth life and breath; and then it beginneth to move it-selfe ${ }^{\text {? }}$ alone. ... So is there xlvi dayes from the day of conception vnto the day of ful perfection and receyuing of the soule, as God best knoweth.'

The anatomy and the philosophical speculations are alike transitory; both passed with the coming of neve knowledge and new ways of thinking, methods of forming ideas. And as such we treat them - transitorye But they were important to us as carriers of a morafi 
tradition; they provided the forms in which moral judgements were expressed and degrees of culpability were decided. Twenty years or so after Vicary's death Pope Sixtus V (31) in October 1588, summarily abolished the tradition which attached culpability to the development of the fetus, whether it were formatus and animatus or still informis and inanimatus:

'By this our constitution, to be valid in perpetuity, we decree and ordain that all henceforth who by themselves or by the hand of any intermediary procure the abortion or ejection of an immature fetus, whether animate or inanimate, formed or unformed, ... and also the pregnant women themselves who knowingly do the same, shall incur, by the very act (eo ipso) the penalties set forth and inflicted by divine as well as human law against actual murderers (veros homicidas)'.

Included in the same condemnation is the giving of potions to induce sterility or to prevent conception. And the penalty was excommunication ipso facto without the possibility of absolution even at the point of death.

Moralists and canonists alike received the bull with consternation. The next pope, Pius IX (32) was quick to modify it. In May 1591 he permitted local Ordinaries to relax the excommunication, and added:

'The penalties for procuring the abortion of an inanimate fetus or for administering or taking potions to cause women to be sterile we revoke just as if that constitution so far as it concerns these things had never been issued'.

The moralists were thereby freed to resume their casuistry.

Cornelius a Lapide, SJ, in his Commentary on the Pentateuch, 1617, expounded the Hebrew and the Greek variants in Exodus 21: 22f, quoting both. He equates the guilt incurred by causing the death of the fetus with that of causing the death of the mother only if the fetus is iam animatus. He interprets the Greek, exeikonismenon, as virunculus, uti flandrice puerum vocamus manneken, 'a little man, called in Flemish a manneken'.

'that is, if the child is shaped or formed (effigiatus vel efformatus), as if to say: If the child has its members perfect, so that it is fully shaped, as if it were what one might call a tiny man (quasi parvus quidam vir) or virunculus; then he who by his blow causes the pregnant woman to miscarry shall give life for life. . . . And from those words of the Septuagint it is clear that the fetus is animated at the time when it is formed (simul atque formatus est, animari); for on that account he who has caused it to miscarry is accounted and punished as one who commits homicide. And the Doctors teach the same' (33).

John de Lugo, SJ, a little later, in Responsa Moralia, 1651, applying the principle of secondary or double effect when a medicine given to a mother for her good causes her to miscarry, writes:

'If the medicine has use for the life of the mother but as an unintended consequence causes her to miscarry, then, so be that the fetus is not animated, the use is licit' (34).

A century later St Alphonsus Liguori, the most celebrated pastor and writer on moral and spiritual theology of his time, who was canonised in 1839, and whom Pius IX was to declare a Doctor of the Church in 1871, expounded the casuistry of the question in his Theologia Moralis (35). His treatment of it, however, will be most easily studied in the text of an editor who had to accommodate his teaching to the intervention of Pius IX in 1869. By the mid-nineteenth century advances in medicine were making abortion by direct assault upon the fetus both possible and safer, supplanting the indirect methods employed hitherto. The incidence of abortion therefore rose. The rise was seen as a moral threat calling for drastic remedy. Pius IX therefore declared excommunicate all who procured abortion, without distinction either as to the method, direct or indirect, intentional or involuntary, or as to the gestational age of the fetus, whether it were formed or unformed, animate or inanimate (36). This sentence is repeated in the most recent edition of the Codex Iuris Canonici, 1983 (37).

The effect of Pius IX's bull is seen in an edition of Liguori's Theologia Moralis published with an imprimatur in 1896. He sets out, first the principles, then the questions arising, concerning abortion.

'190. Principles. I. It is never lawful directly to procure an abortion, even though the fetus may be supposed to be still inanimate. And for this reason: that, if the fetus is animate, homicide properly so called is committed, and that the more heinous because very often the soul is at the same time deprived of eternal life; if it is not yet animate, it is nevertheless alive (vivus), and is unjustly prevented from becoming man, and this is, so to speak (velut) anticipated homicide; and in consequence this is more unnatural (contra naturam) than pollution. . .'

The second Principle applies 'double effect' to permit indirect abortion resulting from a remedy necessarily administered to a pregnant woman to obviate a threat to her life - provided that no other remedy were available, and that the fetus were not deprived of a reasonable hope of baptism.

Then come the Questions.

'192. Question 1. At what time is the fetus informed with a rational soul? Response: That it is infused once the body is sufficiently formed, at the thirtieth or fortieth day in fact, is certain, and so many hold. It is, however, more probable, and today commonly accepted, that it is infused at the very moment of conception; the rational soul, indeed, is the form which 
fashions the organic body (forma plasmativa corporis organici) or forms the human organism. This is confirmed by the feast of the Immaculate Conception of the Blessed Virgin Mary. The contrary opinion holds that the body before the organs are formed is not apt to receive the rational soul; but this is a gratuitous claim, and, moreover, it proves too much, for the body does not exist as an instrument apt for rational operations except after birth.

Aristotle, whom the Schoolmen followed, taught that the male fetus was informed with a rational soul on the fortieth day, the female on the eightieth; and this opinion the external forum of the Church follows (sequitur) so far as ecclesiastical penances are to be incurred, with one exception. That wide disparity between the animation of male and female rests on no solid foundation.

Question 9: Whether those who procure an abortion incur the penalties when there is doubt whether the fetus is or is not animate?

Response 1. So far as excommunication is concerned, the answer must be Yes; for Pius IX makes no distinction between the animate and the inanimate fetus.

2. As for the other penalties, the answer should be more truly No (verius negandum) (a) because irregularity is not to be admitted except in cases set down in law; and the Canons speak only of cases which clearly constitute de facto homicide; and in this case, where there is doubt whether the fetus is animate, there is doubt also about the fact of homicide; (b) because in cases of doubt the fact may not be presumed but must be proved; (c) because in the matter of penances, the more favourable interpretation is to be followed. Hence when there is doubt whether the aborted fetus is masculine or feminine, the penalties are not incurred before the eightieth day (38).'

The process of adapting the moral tradition in this text is clear. Aertnys, a Redemptorist Father, expounds as closely as he may the teaching of the founder of his Order, Liguori, but qualifies it where necessary, as he was bound, by rulings of the Papacy and the Holy Office promulgated since Liguori wrote, as well as by authoritative theological opinions. Hence the reliance, not only on Pius IX's Apostolicae Sedis, but also on his bull of 1854 in which he established as an article of the Catholic faith the dogma of the Immaculate Conception of the Blessed Virgin Mary. Running through the cases discussed (and more are omitted here than are cited) runs Liguori's 'equiprobabilism', his teaching that when there is doubt whether substantive law exists, the laxer course is to be followed. And it was for this virtue, perhaps, that he was described by Pius IX as 'the helmsman of the safest course between laxism and rigorism' (laxismi et rigorismi tutissimus depulsor) and by Leo XIII as 'the most prudent of guides for directors of souls (animarum moderatorum prudentissimus dux).

\section{Conclusion}

The aim of this paper has been, not to claim 흠 contemporary relevance for either an outmoded embryology or an outmoded philosophical speculation on the soul and the time of its 'entering' (if it does) theis body; nor yet to ventilate again the liceity of abortion. $\overrightarrow{0}$ It has been to recall a moral tradition expressed in terms of these three things, persisting to the end of thew nineteenth century, and, for those cognisant of the? arcane casuistry of medical practice, well beyond that date. The tradition attempted to grade the protectionaccorded to the nascent human being according to the stages of its development. The tradition is challengediw today by those who claim absolute protection 'from the moment of conception' and so would forbid forms of post-coital contraception (like hormonal compounds $\vec{z}_{\vec{Z}}$ or intra-uterine devices which inhibit implantation), and any use of ova fertilised in vitro not directed? towards their being implanted and brought to term in live birth.

The motive prompting the restriction is admirable: to resist the erosion of the value of human life, alreadyo savagely assailed by the world's present economic ands political activities. But we have to choose. Uterine lifeō must be protected at some point. If we put that pointo too early, forbidding observation and experimental usea of pre-implantation embryos in the early stages of cell $\overrightarrow{5}$ division, we shall inhibit much useful research of 3 potential human benefit, including the improvement? of the chances of successful pregnancy, for lack of which many extra embryos are sacrificed at present. Embryologists themselves search for means off determining a point beyond which experiment would be intolerable; they would relate that point to the beginning of the development of the nervous system, anticipating the capacity of the fetus for sensitivity or awareness - words used by Dante, as we have seen, as characteristic of the fetus so grown as to warrant the attribution of a rational, human soul. Knowledge of embryology may change; but perhaps there are aspects of human relating to it which are perennial.

\section{References and notes}

(1) Human fertilisation: choices for the future. Evidence of the Catholic Social Welfare Commission to the Governmento enquiry into human fertilisation and embryology Abingdon: 1983: section 43: 21.

(2) Chollet A. Animation. In: Vacant A, Mangenot E, eds Dictionnaire de théologie Catholique. Paris: Latouzey et Ane, 1903: col 1305ff.

(3) Delmaille J. In: Naz R, ed. Dictionnaire de droit canonique? Paris: Latouzey et Ane, 1938: col 1536ff. 
(4) Driver G R, Miles J C. The Babylonian laws. Oxford: Clarendon Press, 1953: II: 209-214. Paul S M. The book of the Covenant. 1965. Quoted by Hyatt J R. Commentary on Exodus. London: 1971: 233.

(5) Sigerist H E. A history of medicine. New York and Oxford: Oxford University Press 1951: 1: 430.

(6) Jacobovits I. Jewish medical ethics. New York: Bloch, 1975: 372.

(7) Hippocrates. Nutriment, XLII. In: Jones W H S, ed. The Hippocratic writings. London: Heinemann; New York: Putnam: Loeb Classics; 1923: I.

(8) Aristotle. Balme D M, ed. De generatione animalium. Oxford: Clarendon Press, 1972: 731a.25, 734b.4ff.

(9) Aristotle. De anima. In: Ross W D, ed. The works of Aristotle: vol III; trans. Smith, J A. Oxford: Clarendon Press, 1931: 402a.6ff. See also reference (8).

(10) Aristotle. Thompson D W, ed. Historia animalium. In Smith J F, Ross D, eds. The works of Aristotle. Oxford: Clarendon Press, 1910: IV. VII. 3-583b. (For help in relating this reference to $\mathrm{St}$ Thomas on The sentences I am indebted to Dr Roland Hall of the University of York).

(11) Tertullian. Apologia. 9.8.

(12) St Basil. Ep. clxxxviii. Ad Amphilochium II.

(13) St Gregory of Nyssa. Adversus Macedonianos. Walce H, Schaff $P$, eds. Oxford and New York: Library of Nicene and Post-Nicene Fathers, series 2, vol v, 1893: 320.

(14) St Augustine of Hippo. Quaestionum in Hept. I; II; n80.

(15) Bieler L. The Irish penitentials. Dublin: Institute for Advanced Studies, 1963: 160, 228, 474.

(16) Pope Innocent III. Canon 5.20. De homicidio voluntario vel casuali.

(17) Raymond de Penafort. Summa de casibus poenitentiae. II: I: De homicidio.

(18) Schulz F. Bracton and Raymond de Penafort. Law quarterly review 1945; lxi:288.

(19) Bracton H. De legibus et consuetudinibus Anglie. F 120, 437. Woodbine G E, ed. Cambridge, Massachusetts: Belknap Prass of Harvard U P, 1965: II: 341, 362.

(20) Blackstone. Commentaries. 4th edition, 1770. 1; 129; iv: 388.
(21) Harvey B F, ed. The Westminster Chronicle 1381-1394. Oxford: The Clarendon Press, 1982: 322f.

(22) St Thomas Aquinas. Summa Theologiae, 2a2ae: 64.8.

(23) See reference (22) $S T$, 2a2ae; 64.1.

(24) See reference (22) $S T$, la; 76.1 .

(25) See reference (22) $S T$, la; 76.3.

(26) St Thomas Aquinas. Commentarium in sententiis. Lib III; dist III; quaest 5 , art 2.

(27) Purgatorio. Cant 25: 67-75. In: Bickersteth G L. Dante Alighieri: the divine comedy. Oxford: Basil Blackwell, 1972. See also translator's note: 790 .

(28) Grobstein C. External human fertilisation. Scientific American 1979: 240: 33-43. Grobstein C. From chance to purpose: an appraisal of external human fertilisation. London: Addison Wesley, 1981.

(29) Horstmann C, ed. The early South East legendary or lives of the saints. London: Early English Text Society. Original series, 1887: 87: 319ff.

(30) Vicary T. The anatomie of the bodie of man. First published 1548, re-published and revised by his colleagues at St Bartholomew's Hospital in 1577. Furnivall F J and P, eds. London: Oxford University Press for Early English Text Society. ES L111, 1888. 2nd impr 1930.

(31) Pope Sixtus V. Effraenatum. 1588 Oct 29.

(32) Pope Pius IX. Sedes Apostolica. 1891 May 31.

(33) Cornelius á Lapide, SJ. In pentateuchum mosis commentaria. 1617. Antwerp: Natius, 1623; Paris: Martin, 1630.

(34) John de Lugo, SJ. Responsa Moralia. 1651.

(35) St Alphonsus Liguori. Theologia Moralis. 1753 and 1755.

(36) Pope Pius IX. Apostolicae sedis. 1869 Oct 12.

(37) Codex iuris canonici. Lib VI, Tit VI, can 1398. Libreria Editrice Vaticana, 1983.

(38) Aertnys J, ed. Theologia moralis. Lib III, Tract V, cap IV, art II. Tournai: Casterman; Amsterdam: van Gulick; Utrecht: van Rossum, 1896. 4th edn. 